\title{
Hypoglycemic, antihistaminic and diuretic effects of aqueous extract of Adiantum capillus.
}

\author{
Gulala Qader*, Kawa Dizaye**Taha Mahwi *** \\ *Department of Pharmacology, College of Medicine, University of Solymania, **Department of Pharmacology, College of \\ Medicine, Hawler medical University, ${ }^{* * *}$ Department of Medicine, University of Solymania, Iraq
}

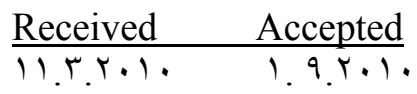

\begin{abstract}
The use of plants for healing purposes predates human history and forms the origin of much modern medicine. Many conventional drugs originate from plant sources, a century ago, most of the few effective drugs were plant based. Adiantum capillus has long held a place in herbal medicine systems worldwide. It is prepared traditionally as an infusion for the treatment of respiratory and urinary disorders. The pharmacological activities of $A$. capillus infusion were evaluated in this study. The result obtained on the rabbit jejunum and bronchial smooth muscle indicated that $A$. capillus extract has attenuated the response to histamine, suggesting antihistaminergic mechanism in the observed effect. The extract showed no significant effect on the contraction of the jejunum and bronchial smooth muscle induced by pilocarpine. Therefore the antihistamine effect of the extract was not associated with antimuscarinic activity. A. capillus has produced a significant increase in the urine flow and urinary $\mathrm{Na}^{+}$and $\mathrm{K}^{+}$excretion rate in rabbits. This effect of $A$. capillus act at site before the distal nephron. The infusion of the plant produced a non significant slight reduction in the blood pressure without affecting the heart rate of the rabbit. The hypoglycemic effect of $A$. capillus extract was studied in alloxan-diabetic rabbits. The extract induced a significant hypoglycemic effect after oral administration which had similar efficacy to the hypoglycemic effects of metformin. The maximal rate of decline in blood glucose concentrations response was observed on the sixth day of the procedure.
\end{abstract}

Keywords: Adiantum capillus. diuretic. antihistaminic, antihyperglycemic

ان استعمال النباتـات للأغر اض العلاجيـة تعود الى عهود تسبق تـأريخ البشرية وتعد الاسـاس للادويـة الموجودة حديثًا.

الكثير من الأدوية التقليدية منشأها اصول نباتية. الكثير من الاستعمالات الطبية للنباتات تطورت من خلال مشاهدة ورصد

الحيو انـات البريـة. (Adiantum capillus) احد الاعثـاب الطبيـة التي لها تأثير جيد لعلاج الربو، ذات الجنب ويعمل

كمدرر للبول. في هذه الدر اسة تم تقيم التأثيرات الدوائية لهذا النبات كما وتم تقيمه كمضاد حيوي. نتيجة العمل على العضلة

الملساء للأمعاء الدقيقة والقصيبات الهو ائية ظهر بأن (Adiantum capillus) يقلل تأثير الأستجابة للهستامين، اي تعمل

كمضاد للهنتامين كما واظهرت الدراسة عدم تأثثر المادة على تصحيح التقلص الحاصل نتيجة استعمال ال (Pilocarpin)

اي أنه لا يعمل ك (Anticholinergic). كمـا ويعمل كمدرر للبول وتزيد نسبة تدفق أو التخلص من

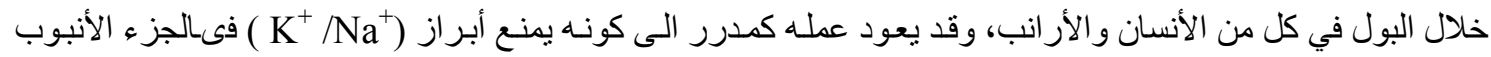

الكلوى الخلفي. تؤثر المادة بنسبة قليلة تكاد تكون غير محسوسة احصائيا على انخفاض ضغط الدم الذي قد يعود الى عمل

المادة كمدرر للبول بينما ليس للمـادة اي تأثير على سـر عة القلب.تخفض المـادة المستخلصـة نسبة الكلوكوز في الدم عند

استعمالها لأرنب مصاب بداء السكري حيث ان عملها يثابه (Metformin). 
$\mathbf{H}$ erbal medicine is the oldest form of healthcare known to mankind. It is an integral part of the development of modern civilization. Much of the medicinal use of plants seems to have been developed through observations of wild animals, and by trial and error '. In a cave in northern Iraq, scientists found what appeared to be ordinary human bones. Analysis of the soil around the bones revealed extraordinary quantities of plant pollen that could not have been introduced accidentally at the burial site. Someone in the small cave community had consciously gathered eight species of plants to surround the dead man. Seven of these are medicinal plants still used throughout the herbal world ${ }^{r}$. Indeed, well into the $r \cdot$ th century much of the pharmacopoeia of scientific medicine was derived from the herbal lore of native peoples. Many drugs, including strychnine, aspirin, vincristine, curare, and ergot, are of herbal origin. About onequarter of the prescription drugs dispensed by community pharmacies in the United States contain at least one active ingredient derived from plant material ${ }^{r}, r$. Adiantum capillus has long held a place in herbal medicine systems worldwide. In the Peruvian Amazon, the local people prepare the fronds of the plant as an infusion or syrup for the treatment of urinary disorders, colds, rheumatism, heartburn, gallstones, and sour stomach ". This plant is also used widely throughout the world for dandruff, alopecia (hair loss), and menstrual difficulties. The plant has demonstrated little toxicity. However, in animal studies, it has been shown to have an anti-fertility effect ${ }^{\circ}$. Despite the plant's ancient history of use for respiratory disorders, no clinical research has been done to validate these traditional uses. The study is undertaken to evaluate the pharmacological effects of $A$. capillus extract, because very little information and studies are available about the medicinal effects of this plant which exists in Kurdistan of Iraq.

\section{Materials and methods}

Preparation of the plant extract: In April, the fresh clean leaves of $A$. capillus were collected from Shwan district in Kurdistan of Iraq. The leaves were shade dried for three days, One $g$ of the crushed plant material was macerated in $0 \cdot \mathrm{mL}$ of boiled distilled water in a conical flask for

$r \cdot$ minutes and filtered. An equivalent of $r$. mg dried material per $\mathrm{ml}$ aqueous infusion was obtained.

Rabbits: Local domestic rabbits (Oryctolagus cuniculus) were used for in vivo and in vitro studies. In the animal house the rabbits were kept in a suitable room temperature $\left(1 \Lambda_{-} Y_{0}{ }^{\circ} \mathrm{C}\right)$ and were fed barley and vegetables. The weight of the animals ranged between $1 . \cdot$ to ${ }^{\prime} . \wedge \mathrm{kg}$.

Tension studies (Isolated Rabbit jejunum): The rabbits were sacrificed and the abdomen was opened rapidly. The stomach was identified then was followed down by $\left.0_{-}\right) \mathrm{cm}$ to exclude the duodenum, when the jejunum was reached; ${ }^{\circ} \mathrm{cm}$ of it was cut and put in a petri dish containing aerated, freshly prepared Tyrode solution). One end of the jejunum is ligatured to a $\mathrm{J}$ shaped tube by monofilament nylon; the other end is ligatured to a frontal transducer for tension and magnification. The preparation is put vertically in an organ bath containing Tyrode solution which was aerated through the $\mathrm{J}$ shaped tube. The aeration with oxygen was for tissue survival and it also helps in better mixing of the added drugs and chemical substances with the Tyrode solution. The temperature of the organ bath is set at $r v{ }^{\circ} \mathrm{C}$ to obtain optimal activity of the tissue. After the piece of jejunum was set in the organ bath, it was left for $r \cdot \min$ to equilibrate before any recordings were made. Meanwhile, the physiological solution was washed and replaced every 10 minutes. 
Isolated bronchial muscle: Bronchial muscles were obtained from a freshly sacrificed rabbit. r- $\varepsilon \mathrm{cm}$ of the bronchus was taken and put in a petri dish containing Krebs solution. A spiral strip of $r-r \mathrm{~cm}$ long was put vertically in an organ bath containing Krebs solution in a temperature of $r v{ }^{\circ} \mathrm{C}$. The isolated tissue was left to equilibrate for $r \cdot-\leqslant 0$ minutes. The contractions were recorded on a physiological recorder

Anesthesia for rabbets: Rabbits were anaesthetized by intra peritoneal (I.P) injection of a combination of Ketamine ( ketamine hydrochloride, Rotex media GMBH, TRITTAU, Germany) in a dose of $r \cdot \mathrm{mg} / \mathrm{kg}$ body weight with (phenobarbital Ibn Hayyan pharma,- Syria) . This combination provided perfect surgical anesthesia, and supplementary small doses of the combination were given as necessary to maintain the level of anesthesia.

Determination of arterial blood pressure and heart rate The arterial $\mathrm{BP}$ was recorded by connecting the common carotid artery cannula to a blood pressure transducer (Washington, pt $\varepsilon \cdot \cdot, \mathrm{S} / \mathrm{N} r \cdot \varepsilon$, supplied by Elcomatic Ltd, England). The arterial cannula connection was through a r- ways stop-cock attached to a syringe containing heparenized isotonic saline. The blood pressure transducer was in turn connected to two channel oscillographs and to a mercury mannometer for calibration. The process of calibration allows the determination of the range of pressure in which the blood pressure of the animal is recorded.The HR was recorded throughout experiments from the BP trace after increasing the speed of the recorder which makes recorded pulses appear as clear waves that could be readily counted per unit of time.

\section{Urine collection}

Urine samples were collected via the urethra by perurethral catheterization of the urinary bladder by small size pediatric feeding tubes. At the end of each urine collection period ( $r \cdot \min )$, the bladder was further emptied by applying adequate and gentle pressure to the lower abdomen above the bladder using the thumb and index finger. The urine was analyzed for sodium and potassium by flame photometry (Jenway, PFP ${ }^{\vee}$ ).

\section{Preparation of alloxan}

Diabetes was induced in rabbits by injection of 1 $\leqslant \cdot \mathrm{mg} / \mathrm{kg}$ IP of alloxan. Six days after injection the blood samples were collected from the ear vein. The blood glucose level was monitored by using glucometer. Diabetes was confirmed in rabbits having FBS levels above $1 \wedge$. $\mathrm{mg} / \mathrm{dl}^{\top}$. The diabetic rabbits were divided into three groups (A, B and $\mathrm{C}$ ), of six rabbits each. The plant extract $r \cdots \mathrm{mg} / \mathrm{kg}$ was administered orally to group A. The reference drug Metformin $(r \cdot \mathrm{mg} / \mathrm{kg})$ and placebo were also administered orally for animals in group B and C, respectively. The above treatments were carried out in each group of animals for 1 - consecutive days. The blood glucose level was monitored after 1, r, 7 and $1 \cdot$ days. Blood glucose levels were expressed in $\mathrm{mg} / \mathrm{dl}$ as mean \pm SEM. The data were statistically analyzed by using complete randomized design (CRD) with different replicates, and then the least significant difference (LSD) test was used for comparison between means ${ }^{\mathrm{V}}$.

\section{Results}

In vitro studies effects of $A$. capillus on the pendular movements of the isolated jejunum of the rabbit: The effects of $A$. capillus $(0 \cdot \mu \mathrm{g} / \mathrm{ml})$ extract on the jejunum smooth muscle are not clear, and no detectable changes have been observed. However, the similar concentration of the plant extract could reverse the contraction of jejunum smooth muscle induced by 1 . $\mu \mathrm{g} / \mathrm{mL}$ of histamine (Figures $1 \& r$ ).

Effects of $A$. capillus on the isolated bronchial muscle: Histamine $(1 \cdot \mu \mathrm{g} / \mathrm{mL})$ produced dose dependent contraction of bronchial smooth muscle which was affected by $A$. capillus ( $0 . \mu \mathrm{g} / \mathrm{ml})$. A. capillus did not reverse the contraction of bronchial smooth muscle which was induced by pilocarpine $(\because 1 \mathrm{mg} / \mathrm{mL})$. 
Whereas the effects of pilocarpine was clearly inhibited by using of atropine $(\cdot$.

$\mathrm{mg} / \mathrm{ml})$ Figure.r.

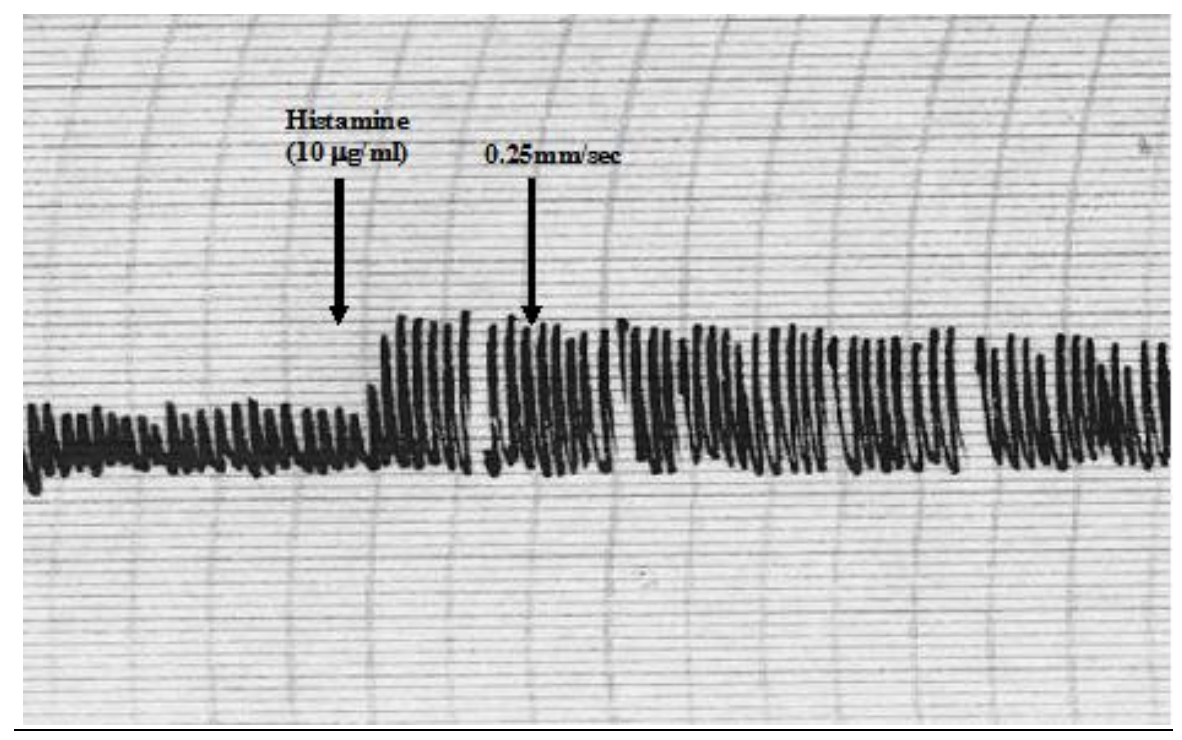

Figure 1 . The effect of histamine $(1 \cdot \mu \mathrm{g} / \mathrm{ml})$ on the jejunum smooth muscle of the rabbit.

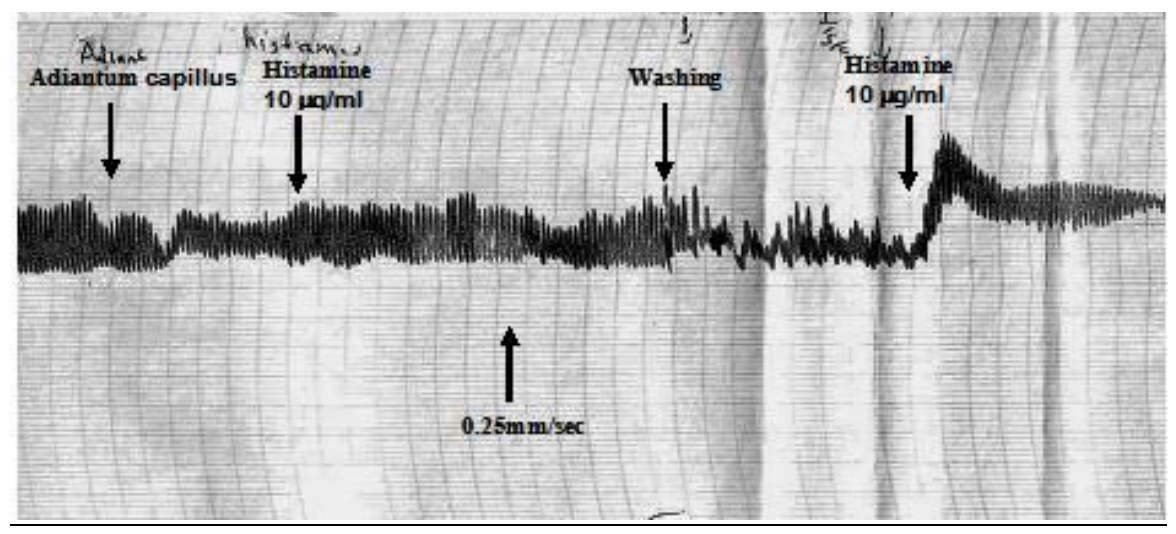

Figure $r$. The effects of $A$. capillus $(0 \cdot \mu \mathrm{g} / \mathrm{ml})$ on the contractile effect of histamine $(\mathcal{l} \cdot \mu \mathrm{g} / \mathrm{ml})$ on jejunum smooth muscle 


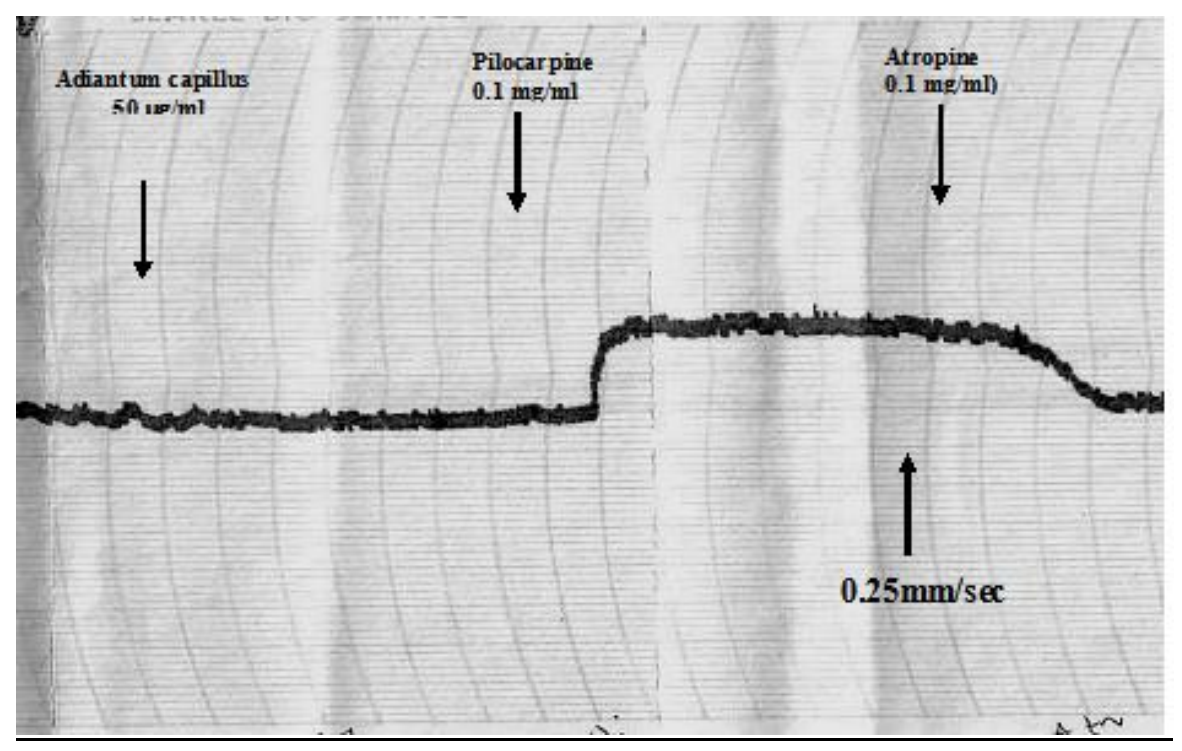

Figure $r$. The effect of $A$. capillus on the contractile effects of pilocarpine on the bronchial smooth muscle

In vivo studies effects of $A$. capillus on the kidney function, heart rate and blood pressure in the rabbit:

The effects of $1 \cdot \mathrm{mg} / \mathrm{kg}$ of $\mathrm{A}$. capillus extract on the urine electrolyte, urine flow, blood pressure and heart rate in the rabbit are shown in Table 1. The plant extract induced significant increase in urine flow, sodium and potassium excretion. The infusion of the plant produced non significant slight reduction in the blood pressure without perceivable effects on the heart rate of the rabbit Table $r$ and Figure $\varepsilon$.
Effects of $A$. capillus on the blood sugar in alloxan-induced diabetic rabbits

The effects of $r . . \mathrm{mg} / \mathrm{kg}$ of A. capillus (PO) on the blood sugar in the rabbit after induction of diabetes by alloxan are shown in Table r. A. capillus produced remarkable reduction in the fasting blood sugar; the efficacy of the plant in the reduction of blood sugar was similar to the hypoglycemic effects of metformin. A maximum response of hypoglycemic effect of the plant extract was observed on the sixth day of the procedure 
Table 1. Effects of $1 \cdot \mathrm{mg} / \mathrm{kg}$ of Adiantum capillus extract on the arterial BP, heart rate and urinary electrolyte excretion rates of the rabbits $(\mathrm{N}=7)$

\begin{tabular}{|c|c|c|c|}
\hline Parameters & Control & $\begin{array}{c}\text { Adiantum } \\
\text { capillus } \\
1 . \mathrm{mg} / \mathrm{kg}\end{array}$ & $\%$ Change \\
\hline $\begin{array}{c}\text { Arterial } \\
\mathrm{BP}(\mathrm{mmHg})\end{array}$ & $\vee \wedge \pm 0$ & $V \varepsilon .0 \pm 7$ & -0.1 \\
\hline Heart rate & $r r \cdot \pm r .1$ & $r r O_{ \pm}$. & $+r$ \\
\hline $\begin{array}{c}\text { Urine flow } \\
\mathrm{ml} / \mathrm{Kg} / \mathrm{hr}\end{array}$ & $0 . V \pm r . \wedge$ & 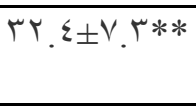 & $+\leqslant 7 \lambda$ \\
\hline $\begin{array}{c}\mathrm{Na}^{+} \text {Exc. Rate } \\
\mathrm{mEq} / \mathrm{Kg} / \mathrm{hr}\end{array}$ & $\varepsilon . V \pm V . r$ & $7 V .1 \pm 0.1 *$ & $+I T Y V$ \\
\hline $\begin{array}{c}\mathrm{K}^{+} \text {Exc. Rate } \\
\mathrm{mEq} / \mathrm{Kg} / \mathrm{hr}\end{array}$ & $1 . r \pm 1.7$ & K. $V_{ \pm} r .0 *$ & $+\wedge \vee\urcorner$ \\
\hline
\end{tabular}

$* \mathrm{P}<\cdot .0, * * \mathrm{P}<\cdot . \cdot 1$

Table $r$. The effects of $r \cdots \mathrm{mg} / \mathrm{kg}$ of Adiantum capillus (PO) on the blood sugar in diabetic rabbit $(n=1 \wedge)$

\begin{tabular}{|c|c|c|c|c|c|c|c|}
\hline \multirow[t]{2}{*}{ Parameter } & \multirow{2}{*}{$\begin{array}{l}\text { Diabetic } \\
\text { rabbit } \mathrm{mg} / \mathrm{dl}\end{array}$} & \multirow{2}{*}{$\begin{array}{l}\text { Ist }^{\text {st }} \\
\mathrm{mg} / \mathrm{dl}\end{array}$} & \multirow{2}{*}{$\begin{array}{l}\mu^{\text {rd }} \text { day } \\
\mathrm{mg} / \mathrm{dl}\end{array}$} & \multirow{2}{*}{$\begin{array}{l}\text { Tth day } \\
\mathrm{mg} / \mathrm{dl}\end{array}$} & \multirow{2}{*}{$\begin{array}{c}\text { 1 } \cdot \text { th day } \\
\mathrm{mg} / \mathrm{dl}\end{array}$} & \multicolumn{2}{|c|}{ LSD } \\
\hline & & & & & & $\because .0$ & $\because \cdot 1$ \\
\hline Placebo & $19 \vee . \wedge \pm 1 r . r$ & $\begin{array}{c}19 . .0 \pm \\
7.8\end{array}$ & $11 . \pm \leqslant .0$ & $|1| \pm 0$ & $V \varepsilon \pm \leq . r$ & 11.07 & $Y \leq . \varepsilon$ \\
\hline $\begin{array}{l}\text { Adiantum } \\
\text { ఛ.. mg/kg }\end{array}$ & $r \cdot v .0 \pm 1 \cdot . r$ & $\begin{array}{l}\text { IVA. } \\
\text { r.ra }\end{array}$ & $\begin{array}{c}10 . \mathrm{r}^{\mathrm{r}} \pm \\
\varepsilon . \wedge \mathrm{b}\end{array}$ & $110 \pm 0.9 \mathrm{c}$ & $1.1 \pm 7.7 \mathrm{c}$ & 19.17 & Y.. T \\
\hline $\begin{array}{c}\text { Metformin } \\
1 \cdots \mathrm{mg}\end{array}$ & $r(r . r \pm 10.1$ & $\begin{array}{c}179.0 \pm \\
1 .\end{array}$ & $\begin{array}{l}\text { Iro } \\
\pm \text { Ir.A }\end{array}$ & $9 \vee .0 \pm 11.1$ & $\lambda r \pm 11 . \varepsilon$ & rq & $r 9.0$ \\
\hline
\end{tabular}




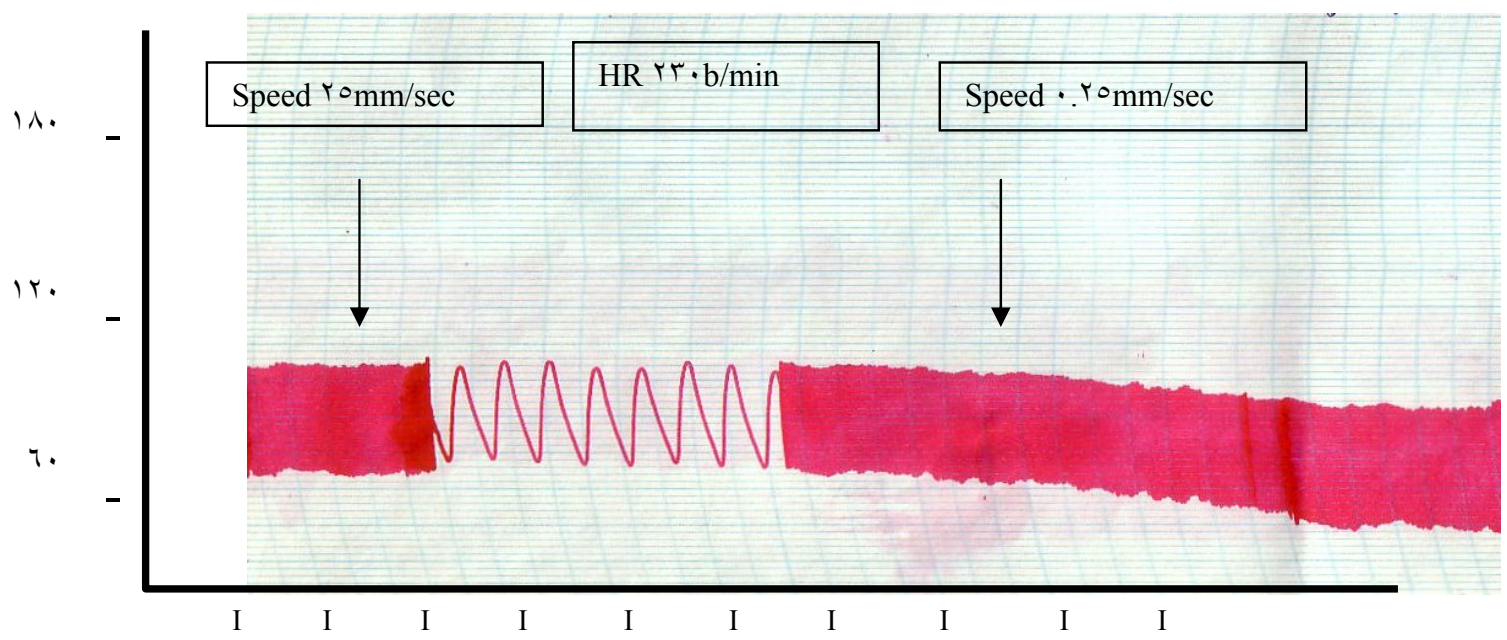

Figure $\leqslant$. The effect of Adiantum capillus $(1 \cdot \mathrm{mg} / \mathrm{kg}$ ) on the blood pressure in the experimental rabbit

\section{Discusion}

\section{Effects of $A$. capillus on the pendular movements of the isolated jejunum of the rabbit}

The infusion of $A$. capillus has inhibited the effects of histamine on the jejunum smooth muscle, indicating the antagonistic effects of the active constituent of the plant on $\mathrm{H}^{\prime}$ (histamine receptor). The result reveals that the plant has no reversal effects on the action of pilocarpine on the contraction of jejunum smooth muscle as well. In addition, it demonstrates that the plant extract has no any anti-muscarinic effects such as dry mouth, urinary retention and tachycardia which is mainly associated with the use of some of histamine $\left(\mathrm{H}_{1}\right)$ receptor blockers such as diphenhydramine and chlorpheniramine ${ }^{\wedge}$. Effects of $A$. capillus on the isolated bronchial muscle

A. capillus has no direct action (dilatation and constriction) on bronchial muscle, it has no direct action on adenosine ArB receptors which leads to degranulation of mast cell to release autacoids, like histamine and prostaglandin from the mast cells on its activation ${ }^{q}, '$. Moreover the $A$. capillus has no muscarine receptor agonist and antagonistic activity. The reversal action of $A$. capillus on the contraction induced by histamine indicates the antihistamine effect of the plant on $\mathrm{H}^{\prime}$ receptor of bronchial muscle.

Effects of $A$. capillus on the kidney functions of the rabbits

The intravenous infusion of $A$. capillus in rabbit induced statistically significant $(\mathrm{P}<\cdot ., 0)$ rise in the urine flow and urinary sodium and potassium excretion rates Table 1. These indicate that this diuretic compound is not similar to potassium sparing diuretic such as triametrine and spironolactone, since $A$. capillus did not cause potassium retention. loop diuretic. The probable site of action is at part of nephron before the distal tubules". Effects of $A$. capillus on the blood sugar of diabetic rabbits

The currently available oral antihyperglycemic agents for clinical use possess characteristic profile of side effects $^{\text {'r, }}{ }^{i r}$. The management of diabetes with agents devoid of any side effects is still a challenge to the medical system. This has led to an increase in the demand for natural products with hypoglycemic activity having fewer side effects. In the present study, the antihyperglycemic activity of leaves of aqueous extract was evaluated in alloxan-induced diabetic rabbit. Alloxan, a $\beta$-cytotoxin, induces "chemical diabetes" in a wide variety of animal species including rabbit. Although the precise mechanism of alloxan-induced 
diabetes remains unclear, there is increasing evidence that it involves the degeneration of islet-cells by accumulation of cytotoxic free radicals ' ${ }^{\text {. Alloxan }}$ causes time - and concentration-dependent degenerative lesions of the pancreatic $\beta$ cells. The dose of alloxan required to produce diabetes varies with the species.A single daily administration of plant extract in diabetic rabbit, showed significant reduction in serum glucose level after $1, r$, 7 and 1. day interval. The maximum reduction in serum glucose level was seen in the sixth day. There were no significant differences in the hypoglycemic activity of the plant extract with that of metformine. The hypoglycemic effect of the plant extract also might be contributed to the presence of insulin-like substances in the plant materials ${ }^{10}$, stimulation of $\beta$ - cells to produce more insulin ${ }^{14}$ or the regenerative effect of plants on pancreatic tissue ${ }^{i v}$.These observations confirm the use of this plant in ethno- medical practice for diabetes management and demonstrated that treatment for 7 days can show more effectiveness than single dose of acute treatment. This study warrants the investigation to isolate and identify the hypoglycemic principles and to elucidate their exact mechanism of action.

\section{Conclusion}

A. capillus extract has antihistaminic $\left(\mathrm{H}_{1}\right)$ activity. It has produced a significant increase in the urine flow and urinary $\mathrm{Na}+$ and $\mathrm{K}+$ excretion in rabbit, the probable site of action is at part of nephron before the distal tubules. The plant extract has hypoglycaemic efficacy similar to those obtained by metformin. The maximal rate of decline in blood glucose concentrations response was observed on the sixth day.

\section{Reference}

'-Blumenthal M, Goldberg A, Brinckmann J (eds). Herbal Medicine: Expanded Commission E Monographs. ' st ed., Newton, MA:
Integrative Medicine Communications. $r \ldots . \wedge$. 10

r- Farnsworth NR, and Morris R. Higher plants. the sleeping giant of drug development. Am J Pharm 19v : $\leqslant$.

r. Bensky D. and Gambl, A. Chinese Herbal Medicine. Materia Medica (revised edition). Eastland Press Inc., Seattle. 199r

¿- Stuart, M. The Encyclopedia of Herbs and Herbalism Orbis Publishing. London. $19 \vee 9$ ISBN •-107/ r_. $7 V_{-} Y$.

○- Murthy, R. Anti-implantation activity of isoadiantone." Indian Drugs.

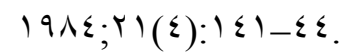

7. Dubey G, Dixi S, Singh A. Alloxaninduced diabetes in rabbits and effect of a herbal formulation D- $\varepsilon .$. . Indian J Pharmacoly $199 \leqslant ;$ Y 4 YYO_rY

$\checkmark$-statistic references Daniel, W. Biostatics: A foundation for analysis in the health science. Third edition 19ᄉr. New York.

^-Arnes L, McKenzie A, Webster D, Poinsett-Holmes K. A new nonsedating antihistamine. Ann. Pharmacother 199r; rV: $\left\{\tau \leqslant \_\leqslant \vee \cdot\right.$

१. Choi, O., Shamim, M., Padgett, W., Daly, J. Caffeine and theophylline analogues: correlation of behavioral effects with activity as adenosine receptor antagonist and as phosphodiesterase inhibitors. Life Sci

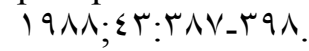

1.- Bertil B, Adriaan P, Ijzerman A., et al. Classification of adenosine receptors. Vol. or, Issue r... 1 , orv_oor, r.

11 - Carter, B. L., Ernst, M. E., and Cohen, J. D. Hydrochlorothiazide versus Chlorthalidone. Evidence Supporting Their Interchangeability. Hypertension $r$.. $\leqslant ; \leqslant r: \varepsilon-q$.

Ir- Holman RR, Turner RC. Oral agents and insulin in the treatment of NIDDM. In: Pickup J, Willians G, editoris. 1991, Textbook of Diabetes Oxford: Blackwell.

1T. Kameswara Rao B, Kesavulu MM, Giri R, Apparao Ch. Herbal Medicines in the treatment of diabetes mellitus. 
Irq J Pharm Vol. ' ', No. ', r. 11

Manphar Vaidya Patrika 199v; I:rr$\circ$.

I \&- Halliwell B, and Gutteridge JMC. Free radicals in Biology and Medicine. 1994 rnd Ed. Oxford: Clarendon Press.

10. Collier E, Watkinson A, Cleland CF, Roth J. Partial purification and characterization of an insulin-like material from spinach and lemna gibba $\mathrm{G}^{\mathrm{r}}$. J Biol

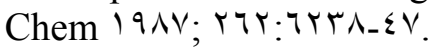

17 Chang MW, Johnson MA. Effect of garlic on carbohydrate metabolism and lipid synthesis in rats. $J$ Nutr 1991; 11.:941-r4.

IV-Chakravarthy BK, Gupta S, Gambhir SS, Gode KD. Pancreatic beta cell regeneration: A novel antidiabetic mechanism of Petercarpus marsupium. Indian J Pharmacol 191.;1 r: 1 rr. 